Dorota Krystyna REMBISZEWSKA

\title{
REGIONALIZMY \\ W JĘZYKU BIAŁOSTOCKICH STUDENTÓW
}

Jak wiadomo, czynnik "pochodzeniowy” (Kurkowska 1991,184) wpływa na ukształtowanie się każdego idiolektu i decyduje o powstaniu językowych przyzwyczajeń. $Z$ badań nad mową inteligencji wywodzącej się ze środowiska wiejskiego wynika, że "wyniesiona” z domu wymowa i sposób wykorzystania niektórych wyrazów, funkcjonują także poza rodzimym środowiskiem. Badacze coraz częściej dostrzegają zjawisko swoistego bilingwizmu mieszkańców wsi, którzy przechodzą z jednego kodu językowego na drugi, w zależności od sytuacji komunikacyjnej. W pracach nad współczesną polszczyzną podkreśla się, że przemienne posługiwanie się gwarą lub odmianą regionalną prowadzi $w$ rezultacie nie do zamiany jednego systemu językowego na inny, lecz do nakładania się systemów pozostających w kontakcie (Kąś, Kurek 2001, 443).

Celem tego artykułu jest próba pokazania, na wybranych przykładach, jak uwarunkowania środowiskowe wpływają na sprawność językową i repertuar zachowań językowych użytkowników polszczyzny wywodzących się ze środowisk wiejskich. Za materiał ilustracyjny posłużą mi prace zaliczeniowe $\mathrm{z}$ dialektologii studentów filologii polskiej Uniwersytetu w Białymstoku.

Przez trzy kolejne lata studenci mieli za zadanie przygotowanie regionalnych słowniczków, w których notowali rozpoznane przez siebie leksykalne regionalizmy i dialektyzmy funkcjonujące $w$ mowie najbliższego otoczenia. Prace te powstawały już po odbyciu cyklu zajęć na temat terytorialnego zróżnicowania polszczyzny, uczestnicy zajęć mieli zatem rozeznanie $\mathrm{w}$ zakresie istniejącego $\mathrm{w}$ Polsce regionalnego zróżnicowania słownikowego i systemowego, poznali też odrębności leksykalne regionu północno-wschodniej Polski. Wydawać by się za- 
tem mogło, że w opracowywanych zbiorkach regionalnego słownictwa, zwłaszcza w definicjach poszczególnych haseł wystąpi wyłącznie materiał ogólnopolski. Stało się jednak inaczej. Silne zakorzenienie w świadomości językowej środowiska zaowocowało nieuświadomianym wprowadzaniem do definiowanych leksemów elementów kodu prymarnego, czyli regionalnej odmiany polszczyzny. Autorzy słowniczków jakby zupełnie nie zdawali sobie sprawy z tego, że niektóre $z$ wykorzystanych przez nich wyrazów, form fleksyjnych, konstrukcji składniowych, typów słowotwórczych, mają ograniczony terytorialnie zasięg występowania. W omawianych pracach dało się także zauważyć jeszcze inne ciekawe zjawisko, mianowicie swoistą hiperpoprawność wyrażająca się obawą przed wyrażaniem się zbyt potocznym, pospolitym. Skutkiem przyjęcia takiej postawy są objaśnienia pseudonaukowei lub nazbyt książkowe, które $\mathrm{w}$ zderzeniu $\mathrm{z}$ definiowanymi regionalizmami i dialektyzmami wywołują niezamierzony efekt komiczny.

Bardzo wyrazistą grupę definicji tworzą objaśnienia zawierające w swym składzie leksykalnym nazwy gwarowe, notowane w Indeksie do krakowskiego Słownika gwar (Indeks 1999).

I tak, gamułka została określona jako 'ukształtowany kawałek, glon'. Glon to wyraz gwarowy oznaczający 'dużą kromkę chleba', oprócz Podlasia znany jest na Warmii i Mazurach (SOWM II: 270).

Gnojówka to 'borta wozu, wykonana $\mathrm{z}$ drewnianych desek, połączona żelazną sztabą, skręconą śrubami'. Słownik gwar notuje bortę jako 'szlak, taśma, obszywka' i wyznacza geografię głównie na zachodzie Polski (SGPA II, z. 3 (6): 393). Z kolei Słownik gwar Ostródzkiego, Warmii i Mazur dodaje znaczenie bliższe temu, które wystąpiło przy definiowaniu omawianego desygnatu - 'brzeg, krawędź grobli, rowu' (SOWM I 207).

Hanucze objaśniono następująco: 'owijki do butów gumowych'. Owijka, zwykle w lm., to 'pas tkaniny służący do owijania nóg, chroniący przed otarciem stóp $\mathrm{w}$ obuwiu gumowym'.

Hołoble 'drewniane koły, przywiązane do konnego wozu, przywiązywało się je za pomocą użw do dugi'. Użwa i duga to nazwy części uprzęży znane przede wszystkim na wschodzie, bo tam wytwarzano charakterystyczne zaprzęgi. Użwa oznacza 'rzemień łączący chomąto z hołoblą' (Janiak 1995: 104), zaś duga 'drewniany kabłąk stanowiący 
część uprzęży w zaprzęgu jednokonnym' (błr., ukr. duhá 't. s.') - nazwa notowana na kresach (Kurzowa 1993: 352), na Podlasiu (Janiak 1995: 67), a także w okolicach Pisza (SOWM II 34).

Kadziałka 'kumatek wełny'. Kumatek, czyli 'zwitek, zwój skręconego włókna' nie jest notowany w słownikach ogólnopolskich.

W oryginalny sposób zdefiniowano ogólnopolski przymiotnik normalny, uznając go za regionalizm i w jego objaśnieniu wykorzystano leksem gwarowy: 'zwyczajny, powszechny, popularny, budny'. Budny 'powszedni, codzienny' (ukr. búdnyj, błr. búdny 't. s.') - wyraz w tym znaczeniu w Słowniku gwar polskich lokalizowany na całym pograniczu wschodnim (SGPA III, z. 1 (7): 50), notowany również pod Sejnami (Zdancewicz 1980: 85), na Podlasiu w Niemirowie w postaci budnovy (Janiak 1995: 63).

Okraśnik 'składówka'. Wyraz składówka w znaczeniu 'spiżarnia' notowany jest jedynie w słowniku gwarowym (SGPK V: 146).

Skrajka 'piętka chleba'. Piętka - 'pierwsza nacięta z bochenka chleba kromka' (SGP III 102).

Regionalizmy wystąpiły także w objaśnieniach niektórych gatunków grzybów: pliska 'kurka', tzn. 'grzyb jadalny, kurka - pieprznik jadalny: Cantharellus cibarius'; podbiereźniak 'koźlak', tzn. 'grzyb jadalny, który rośnie pod brzozami, koźlarz: Leccinum scabrum'.

Część pługa - sośnik została zdefiniowana za pomocą synonimu: 'lemiesz' 'stalowy klin pługa krojący ziemię od spodu', który znany jest wielu gwarom, m.in. na Mazowszu (AGM IV 156).

W dwóch definicjach pojawiły się regionalne rzeczowniki utworzone od archaicznych iteratywów: rozgartywać, wygartywać. (BSE 135, SSE 259). Mamy więc: kruczek 'hak służący do rozgartania żaru lub popiołu w piecu', kociuba 'zakrzywiona blacha zamocowana na kiju, służąca do wygartania pieca $\mathrm{z}$ żaru'.

W analizowanych definicjach pojawiła się również, rozpowszechniona na Białostocczyźnie konstrukcja składniowa, tj. analityczne dla z dopełniaczem, zamiast syntetycznej formy celownika. Spotykamy ją $\mathrm{w}$ definicji wyrazu duha: 'zakładany dla konia zaprzęg wykonany $\mathrm{z}$ drewna'.

W niektórych definicjach pojawiły się ciekawe regionalizmy słowotwórcze utworzone za pomocą charakterystycznych przyrostków. 
Przyrostek -ak, szczególnie produktywny w polszczyźnie północnowschodniej, wystąpił w objaśnieniach odnoszących się do istot niedorosłych: ciela 'cielak', kryjan 'mały dzieciak', porszuk 'prosiak'. W wymienionych przykładach elementem dyferencjalnym jest jedynie sufiks, natomiast podstawy słowotwórcze należą do polszczyzny ogólnej.

Sufiks -awa wystąpił $\mathrm{w}$ definicji rzeczownika oparcysko 'grzęsawisko, trzęsiawa'. Przyrostek ten, tworzący nazwy przestrzeni, znany jest na Suwalszczyźnie (Zdancewicz 1980, 99). Wyraz w postaci trzęsawa 'bagno trzęsące się pod nogami' został zapisany w SGP (V 433);

$\mathrm{W}$ jednym $\mathrm{z}$ objaśnień podano nazwę atrybutywną $\mathrm{z}$ sufiksem -liwy, który zarówno w gwarach, jak i polszczyźnie ogólnej, tworzy formacje wyrażające skłonność osoby do wykonywania czynności oznaczonej czasownikiem (por. Szczepankowska 1998, 79, Wróbel 2001, 196): zajqkliwy 'jąkała'. Podstawą do utworzenia tego derywatu stał się czasownik zajakać się, znany gwarom na Mazowszu w okolicach Sierpca (AGM IX 115) i w Łomżyńskiem (Sędziak 1992, 123). Czasownik ten, obecnie o ograniczonym zasięgu występowania, rejestruje Stownik jezyka polskiego pod red. Doroszewskiego $\mathrm{z}$ kwalifikatorem dawny (SJPDor X 537).

W repertuarze podawanych wyrazów znalazły się formacje utworzone sufiksem -ny (-na): burka 'samorobna, uszyta z sukna; był to długi, ciepły płaszcz noszony na co dzien', dyrda 'teren okolny'. Przyrostek -ny jest produktywny w gwarach pod Sejnami. Jego występowanie T. Zdancewicz traktuje jako przejaw interferencji wschodniosłowiańskiej i podaje przykłady: kierowny 'dający się łatwo kierować' - błr. киро́вны; rozrywny 'wybuchowy, eksplodujący' - błr. разрўны, ros. разрывной (Zdancewicz 1966: 85).

W analizowanych definicjach wystąipiły także inne odstępstwa od normy języka ogólnopolskiego, w zakresie morfologii i składni.

Jeden ze studentów określił fafernuchy jako 'placki z ciasta postowego, pieczone na dużej ilości tłuszczu'. Wyraz postowy (zamiast postny, czyli 'taki, który nie zawiera mięsa i tłuszczu zwierzęcego') może być traktowany jako przejaw seryjności $\mathrm{w}$ tworzeniu derywatów zbliżonych semantycznie, w tym wypadku typu drożdżowy, biszkoptowy. Przyrostek -owy we współczesnej polszczyźnie odznacza się największą aktywnością wśród sufiksów adiektywnych, ma nieograniczoną łączliwość, 
co powoduje nieprecyzyjność i wadliwość tworzonych $\mathrm{z}$ jego udziałem konstrukcji (Jadacka 2001, 101-102).

Czasownik gderać otrzymał określenie: 'mówić do kogoś dokuczliwie'. W definicji użyto przysłówka zamiast właściwszego w tym kontekście wyrażenia z przymiotnikiem dokuczliwy 'przykry do zniesienia' - w sposób dokuczliwy.

W analizowanym materiale mamy przykład regionalnego zastosowania wyrazu zakładać: łoblekać się 'zakładać ubranie', obuć się 'założyć buty'. Użyto go w znaczeniu 'wkładać coś, ubierać się w coś', tymczasem, zgodnie z normą, czasownik zakładać może występować wyłącznie w takich kontekstach, kiedy mowa o przedmiocie, który umieszcza się na sobie, np. zakładać okulary, kolczyki, krawat (Nowy słownik 1999, 1282).

W dwóch definicjach wystąpiły rzeczowniki męskie, którym w dopełniaczu lp. przypisano końcówkę - $a$ zamiast ogólnopolskiego - $u$ : szczytki 'zastawki w wozie w kształcie trapeza', treiniła 'tylna część woza'. Wahanie -a/l-u jest częste, gdyż repartycja końcówek męskiego dopełniacza pojedynczego nie jest do dziś jednoznacznie określona.

W części proponowanych definicji znalazły się wyrazy znamienne dla codziennych kontaktów językowych, familiarnej lub młodzieżowej odmiany polszczyzny, których użycie wynika zapewne z jednej strony $\mathrm{z}$ nieumiejętności wychwycenia różnic stylistycznych, ale $\mathrm{z}$ drugiej staje się niekiedy sposobem na uwydatnienie nacechowania emocjonalnego, wzmocnienie intensywności wskazywanej cechy. O ich nacechowaniu świadczy fakt, że zarówno w Słowniku języka polskiego pod red. B. Dunaja (Słownik 1996), jak i Nowym słowniku poprawnej polszczyzny (Nowy słownik 1999) wyróżnione wyrazy opatrzono kwalifikatorami potoczny lub pospolity: brzochać 'pyskować', chabory 'gnaty, gołe kości, także żebra', chlać 'żreć, czerepacha 'stara, natrętna baba', dziapa 'gęba', farfocel 'zasmarkaniec, ktoś zaśliniony, sepleniący', kulimaga 'pogardliwie o osobie niezdarnej, łamadze', łachmany 'stare ciuchy', nahaj 'pyta do bicia', naodziać 'uderzyć, przyrżnqć', nożnik 'wychodek', rozkaraczyć się 'rozkraczyć się', skibka 'pajda chleba', szałaputra 'roztrzepaniec', pasakieła 'plotkara', wykarabkać się 'wygramolić się', zajakliwy 'jakała'.

W niektórych definicjach zwraca uwagę swoista oszczędność w stosowaniu środków językowych. Na przykład regionalny neosemantyzm baton został zdefiniowany za pomocą regionalizmu 'bułka paryska' 
bez dodatkowego komentarza, który wyjaśniłby, iż jest to 'pieczywo z pszennej mąki o podłużnym kształcie'. Z kolei miękkie obuwie domowe, nazywane na północnym wschodzie łapcie lub wstępki określono mianem 'klapki', które nie w pełni oddaje cechy opisywanego desygnatu.

W wypadku bliskoznacznego regionalnego odpowiednika babka ziemniaczana autor definicji, wychodząc zapewne z założenia, iż jest to wyrażenie powszechnie znane na północnym wschodzie Polski, nie podaje dodatkowej informacji, że jest to 'potrawa z tartych ziemniaków, z dodatkiem przypraw, pieczona w blasze'.

W materiale można znaleźć przykłady nazw ogólnopolskich, którym przypisano status regionalizmów, $\mathrm{z}$ drugiej strony niezbyt fortunnie je objaśniano, w wyniku czego dochodziło do zafałszowania sensów tak powszechnie znanych desygnatów, jak: becik 'pierzynka dla niemowląt', biegun 'część łóżeczka dziecięcego, która służyła do kołysania', firanka 'ozdobna zasłona', kuternoga 'osoba potykająca się'.

W kilku definicjach uwidoczniła się niedostateczna znajomość realiów wiejskich, zwłaszcza w zakresie desygnatów, które już wyszły lub na naszych oczach wychodzą $z$ użycia, jak:

chomato 'część uprzęży, która mieści się na piersi konia', dunica 'to była maszyna do tarcia maku', zamiast 'kamionkowa miska do ucierania maku - makutra';

okrasa 'określenie mięsa, sadła, słoniny', zam. 'roztopiony tłuszcz (czasem z kawałkami mięsa) dodawany do potrawy';

łoni 'ubiegłoroczne plony', zam. 'ubiegłoroczny - w znaczeniu jednostki czasu';

niecka 'drewniana miska, w której rozniecano ciasto drożdżowe', zam. 'drewniana miska do rozrabiania ciasta';

sofka 'łóżko do przechowywania pościeli', zam. 'niska kanapa z miękkimi wałkami zamiast poręczy i oparcia';

stępa 'maszyna do mielenia kaszy gryczanej', zam. 'dawny sprzęt do rozkruszania ziarna na kaszę składający się z drewnianego lub kamiennego naczynia i drewnianego ubijaka'.

Jako signum temporis można potraktować objaśnienia „uwspółcześniające" sens niektórych, nacechowanych już chronologicznie, desygnatów: blin 'zapiekanka z ziemniaków', komoda 'obecnie mówi się seg- 
ment; w komodzie stoją sztućce i talerze', krypa 'wanna tuż przy studni', leżonka 'leżak dostawiony do kuchennego pieca', zasuń na skobel 'zamknij drzwi na klucz', zedel 'rodzaj drewnianego siedzenia, przypominającego kanapę (bez obicia)'.

Zdarzyły się także definicje, w których zwracała uwagę pozorna staranność w doborze środków językowych, chęć odbanalnienia języka, chociażby przez rozbicie stałości związku frazeologicznego. Ta postawa skutkuje tworzeniem konstrukcji zbyt pompatycznych, a przede wszystkim zabawnych:

bastruk 'dziecko z lewego łoża' - innowacja frazeologizmu dziecko z nieprawego łoża przez wprowadzenie rzeczownika lewy ma zapewne dosadniej wskazać naganność zjawiska, jakim jest posiadanie nieślubnego dziecka. Potocznie 'coś, co jest lewe, jest niezgodne z prawem' (Bańko 2000 I 761). We frazeologii wyraz lewy ma zwykle ujemne konotacje: głupi jak but z lewej nogi, mieć dwie lewe ręce, wstać lewa nogq.

kobieta 'człowiek płci żeńskiej',

krakowiaki 'kluski przygotowywane z gotowanych ziemniaków, serwowane łyżką bezpośrednio na talerz i polewane okrasą'; w definicji pojawił się książkowy wyraz serwować, który bywa często nadużywany w znaczeniu podawać;

obrzqdek 'codzienny obchód przy zwierzętach'; aby nadać odpowiednią rangę czynnościom gospodarskim, posłużono się wyrazem semantycznie związanym z definiowaną czynnością, tj. obchód, który oznacza 'przejście ordynatora szpitala wraz z lekarzem i pielęgniarkami po wszystkich salach i sprawdzenie postępów leczenia' (Bańko 2000 I 1055); osełka 'podłużny przedmiot $o$ strukturze cementowej, służący do ostrzenia kosy',

szufelka 'przedmiot na śmieci',

ślurka 'drewniana kabura (z wodą) do wkładania osełki; ślurkę nosił kosiarz z tyłu za pasem'; kabura oznacza 'futerał na krótką broń palną', zatem użyto tu wyrazu kabura w sensie 'futerał na jakiś przedmiot', ale o ściśle określonej dystrybucji znaczeniowej; żuraw 'urządzenie do wydobywania wody ze studni'.

Niezamierzony komiczny efekt wywołują omówienia nadmiernie szczegółowe, w sytuacjach, gdzie ta precyzja jest całkowicie zbędna: asot 'oset, nazwa rośliny o liściach zakończonych igłami, kwitnącej ja- 
snofioletowym kwiatem', kaszkiet 'czapka, to część garderoby do okrycia głowy', skobel 'zamknięcie drzwi; zgięty pręt tworzący uszko, wbijany w drzwi, w celu przełożenia drewnianego kołka lub kłódki'.

Wszystkie przytoczone $\mathrm{w}$ artykule wyrazy otrzymały $\mathrm{w}$ analizowanych pracach studenckich tylko lakoniczne wyjaśnienie znaczenia, rzadko towarzyszy mu kontekst. Definicje są w zdecydowanej większości realnoznaczeniowe, nie odwołują się do budowy słowotwórczej wyrazów. Żadne z objaśnień nie charakteryzuje wyrazu pod względem gramatycznym.

Zgromadzony materiał wskazuje, że przyzwyczajenia środowiskowe, obcowanie na co dzień $\mathrm{z}$ regionalną odmianą polszczyzny mają duży wpływ na nasz sposób mówienia i pisania mimo rozległego codziennego kontaktu z polszczyzną ogólną: przez słowo drukowane, media elektroniczne i dyskurs z użytkownikami polszczyzny spoza wąskiego kręgu lokalnego środowiska.

Ponadto dowodzą stosunkowo niewielkiej wrażliwości na poprawność językową, precyzję wypowiedzi i komunikatywność. Jest to o tyle istotne, że autorami tych osobliwych definicji są przyszli poloniści, od których przecież oczekuje się dbałości o urodę i poszanowanie języka ojczystego.

\section{Literatura}

AGM - A. Kowalska, A. Strzyżewska-Zaremba, Atlas gwar mazowieckich, Warszawa-Kraków 1992.

Bańko M., 2000, Inny słownik języka polskiego, t. 1-2, Warszawa. BSE - A. Brückner, Słownik etymologiczny języka polskiego, Warszawa 1993. Cyran W., 1960, Gwary polskie w okolicach Siedlec, Łódź.

Indeks 1999, Indeks alfabetyczny wyrazów z kartoteki "Słownika gwar polskich", pod red. J. Reichana, t. 1-2, Kraków.

Jadacka H., 2001, System słowotwórczy polszczyzny (1945-2000), Warszawa. Janiak B., 1995, Polsko-ukraińskie zwiazki językowe na przykładzie gwary Niemirowa nad Bugiem, Łódź.

Kąś J., Kurek H., 2001, Język wsi, [w:] Najnowsze dzieje języków słowiańskich. Język polski, red. S. Gajda, s. 440-446, Opole. 
Kurkowska H., 1991, Polityka językowa a zróżnicowanie społeczne współczesnej polszczyzny, [w:] Polszczyzna ludzi myślacych, wybór i opracowanie H. Jadacka i A. Markowski, s. 178-188, Warszawa.

Kurzowa Z., 1993, Język polski Wileńszczyzny i kresów pótnocno-wschodnich $X V I-X X$ w., Warszawa-Kraków.

Nowy słownik 1999, Nowy słownik poprawnej polszczyzny PWN, pod red.

A. Markowskiego, Warszawa.

Sędziak H., 1992, Semantyka i składnia czasowników mówienia w gwarze Łomżyńskiej, Łomża.

SGPA - Słownik gwar polskich, pod kier. J. Reichana, t. 2, z. 3 (6); 1989 t. 3, z. 1 (7), Wrocław-Warszawa-Kraków.

SGPK - J. Karłowicz, Słownik gwar polskich, t. 1-6, Kraków 1900-1911.

SJPDor - Słownik języka polskiego, pod red. W. Doroszewskiego, t. 1-11, Warszawa 1958-1969.

Słownik 1996, Słownik współczesnego języka polskiego, pod red. B. Dunaja, Warszawa.

SOWM - Słownik gwar Ostródzkiego, Warmii i Mazur 1987 i nast., t. 1-3, Wrocław.

SSE - F. Sławski, Słownik etymologiczny języka polskiego, z. 3, Kraków 1983. Szczepankowska I., 1998, Nomina attributiva w gwarze łomżyńskiej, Białystok.

Wróbel H., 2001, Gramatyka języka polskiego, Kraków.

Zdancewicz T., 1966, Wptywy białoruskie w polskich gwarach pod Sejnami, Poznań.

Zdancewicz T., 1980, Mazurzq̨e gwary suwalskie, Warszawa-Poznań. 